\title{
Can the Section of the Splanchnic Nerves or the Removal of the Suprarenal Glands or their Medulla Modify the Glycaemic Effect of Adrenaline?
}

\author{
By \\ Masari Tiba. \\ (千 苝 腳) \\ (From the Physiological Laboratory of Prof. T. Satake, \\ Tohoku Imperial University, Sendai.)
}

Some writers, who found an exaggerated insulin hypoglycaemia on sectioning the splanchnic nerves, expected to see at the same time a diminishing of the adrenaline hyperglycaemia thereby; they were able, they stated, to have the data corresponding to their expectation. Rather an opposite outcome however seems to be likely from an analogy with the paradoxical pupil dilation on adrenaline.

If insuliu and adrenaline be given in a few days afterdividing the splanchnic nerves-this is done mostly on opening the abdominal cavity-, and an exaggeration of the insulin hypoglycaemia and a diminution of the adrenaline hyperglycaemia be obtained, one must take into account altered nutritive conditions causable by that operation, although there are some writers noting a no-lessening influence upon the magnitude of adrenaline hyperglycaemia even after some days of starvation.

In fact the view that sectioning the splanchnic nerves dimishes the magnitude of adrenaline hyperglycaemia was sometimes refuted. Inasmach as some recent writers however seconded that view, I attempted to re-investigate and somewhat extend this problem, as the heading of this paper shows.

Double Splanchnicotomy: How dividing the splanchnic nerves modify the hyperglcaemic effect of adrenaline was first tested much later in comparison to a similar question on the rôle of suprarenal glands, as shown below.

I know only one reference, that of Hirayama $\mathbf{a}^{\mathbf{n}}$ before Dresel and

1) Hira 5 am a, Nippon Igakukwaisli, 1922, 6, 31 ; Tohoku J. of Exp. Med., 1926, 7,346 . 
O monsky, noting the adrenaline hyperglycaemia in the doubly splanchnicotomized rabbits. For the purpose of excluding the fastening diabetes, Hir a y a$m$ a cut the splanchnic nerves two weeks or more before the adrenaline experiment, but he did not attempt to compare the magnitude of adrenaline hyperglycaemia there with that when the splanchnic nerves are remaining untouched. The figures on his Table II tell us the non-influence of the splanchnicotomy upon the magnitude of adrenaline hyperglycaemia, if they be compared with those reported everywhere.

Dresel and $O$ monsky demonstrated, they believe, that the splanchnicotomy largely diminishes the glycaemic response against adrenaline. The figures of Rabbit 2 correspond to the description, but those of Rabbit 1 should be taken on the contrary as showing non-effectiveness of the denervation. (It may be added that the ascending limb of $I$ in Fig. 2 gives the impression that it is not so steep as I in Fig. 1, but this is largely due to the fact that it ascended much steeper 0.5 hour after injection in Fig. 2 than in Fig. 1.) They wrote: Mehrfach vorgenommene Untersuchungen zeigten entsprechende Kurvenbilder; we must then question which of the types. The denervation was done per laparotomiam; how long an interval of time was allowed to elapse between the operation and the adrenaline injection is not found in the paper.

Hi is $m o t o^{3)}$ came in next year to affirm, he stated, the results of Dresel and $\mathrm{O}$ mons $\mathrm{ky}$, only the descending limb of the hyperglycaemia being cut short in his. The results of D.\& O. are not similar, but different, as above discussed, in two rabbits, which are all that they published; and the data given in the paper of $\mathrm{H}$ isamoto (Table 1-8) should be taken as showing non-alteration of the glycaemic response by the double splanchnicotomy of rabbits against adrenaline. His conclusion might have come about from his having been confused by the statement of the previous investigators.

The data which correspond to the statement of $\mathrm{H}$ is am o to were published a few years later by In o y y $\mathrm{e}^{\mathbf{s}} ; 13-15$ days after sectioning the splanehnic nerves per laparotomiam, rabbits were administered with adrenaline when the body weight was somewhat smaller.

$\mathrm{N}$ a k a $t \mathrm{suka} \mathrm{a}^{5}$ was the first who mentioned non-influence of the double splanchnicotomy upon the intensity of adrenaline hyperglycaemia, the average of the maxima in 4 normal rabbits being $0.261 \%$ and that in 5 doubly denervated 0.257 $\%$. At least two weeks after the denervation, the adrenaline injection was done, as usual in both Laboratories, this one and Professor I. F u jii's. In another set of experiments, $0.168 \%$ and $0.160 \%$ were the corresponding figures, on one and the same dose of adrenaline, viz. $0.15 \mathrm{mgrm}$. adrenaline hydrochloride subcataneously.

Recently Bernardini $i^{n}$ denervated the suprarenals in grey rabbits, and

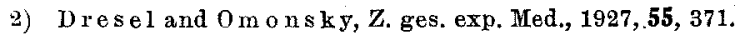

3) His amoto, Okayama Igakkai Zassi, 1928, 2476.

4) In o y e, Nagasaki Igakkai Zassi, 1930, 8, 161.

5) Nakats uka, Mitt. med. Ak. Kioto, 1932, 6, 1351.

6) Id., Ibid., 1427 .

7) Bernardini, Rev. Pat. Sper., 1935, N.S. 3, 15. 
gave adrenaline intravenously in a dose of $0.1 \mathrm{mg}$, which resulted in a hyperglycaemia, but of much smaller magnitude. He took the average, initial as $0.100 \%, 0.190 \% 5$ minutes after adrenaline, $0.175 \% 15$ minutes, $0.161 \% 30$ minutes and $0.143 \% 60$ minutes for 8 normal rabbits, and $0.140 \%, 0.145 \%, 0.129$ $\%$ and $0.113 \%$ respectively for 2 rabbits after the unilateral denervation and the bilateral denervation together. It seems to me rather reasonable to regard the figures each for the unilaterally operated and for the doubly operated; the former is then $0.179 \%, 0.172 \%, 0.158 \%$ and $0.130 \%$ respectively, and the latter 0.125 $0 \%, 0.134 \%, 0.118 \%$ and $0.106 \%$. Therefore the unilateral denervation had no influence upon the adrenaline hyperglycaemia at all, but the bilateral acts to diminish to some extent the intensity of adrenaline hyperglycaemia. But it nunst be remembered that adrenaline was injected on that day of the last denervation or at length 4 days (or 5 days), probably a misprint in Experiment $V$ (on p. 19), later. (Regrettably I was not able to have the paper where B ernardini described with a co-worker the method of denervation, since our Library lacks that volume.)

In this year Mori $i^{8)}$ reported a similar yield with $\mathrm{Nakatsuka;6-7}$ days were allowed to elapse after splanchnicotomy per laparotomiam before injecting subcutaneously $0.15 \mathrm{mgrm}$. per kilo in rabbits.

Double Suprarenalectomy: Much earlier than that an endeavour was made to inject adrenaline into animals after double removal of the suprarenal capsules.

In dogs, Bierry and Mallo iz el $1^{9}$ removed the suprarenals by the lumbar route, and a few hours later adrenaline was injected intraperitoneally; the hyperglycaemia occurred on a much reduced scale, compared with the normal animals.

Non-effectiveness of suprarenalectomy rê adrenaline hyperglycaemia was reported by $\mathrm{K}$ i $\mathrm{c} \mathrm{h},{ }^{107}$ on injecting adrenaline in a subcutaneous dose of $0.5 \mathrm{mgrm}$. into rabbits long surviving double suprarenalectomy.

Shiozawa $a^{11}$ injected adrenaline in a dose of $0.1 \mathrm{mgrm}$. per 100 grms. in rats subcutaneously 2-7 days after double suprarenalectomy per laparotomiam. The results show on the whole non-effectiveness of the suprarenalectomy upon the adrenaline hyperglyeaemia.

Similar conclusion was reached by Mima, who left a small portion of the right suprarenal gland from excising in rabbits. ${ }^{12}$

In enfeebled suprarenalectomized cats, Britton and Silvett $\mathrm{e}^{13)}$ detected a small increase of the blood sugar content on applying adrenaline intraperitoneally.

Viale removed the suprarenals in dogs under chloral narcosis, through the lumbar route and they survived for 48-100 hours. On $1 \mathrm{mgrm}$. adrenaline the

8) Mo ri, Kumamoto Igakkai Zassi, 1937, 13, 557.

9) Bierry and $\mathrm{M}$ alloize 1 , C. r. Soc. Biol., 1908, 65, 932.

10) Kiseh, Kl. W., 1924, 3. year, 1662 .

11) Shi oz aw a, Zikken Igaku Zassi, 1926, 10, 128.

12) Mim a, Nippon Naibunpigaku Zassi, 1927-28, 3, 796.

13) Britton and Silvette, Am. J. of Physiol, 1931 (-32), 99, 15. 
blood sugar content did not increase." Similar experience was reported by Carras co-F ormig u e ra; adrenaline was intravenously administered 22 hours after the last decapsulation which was conducted 10-15 days after the first. ${ }^{15}$ ) (Some words maybe written of the report of $\mathrm{Kahn}$ and Starkenste.in. ${ }^{16)}$ They wrote in the text: Versuch VI zeigt die Wirkung subkutan eingeführten Adrenalins. Die Harnmenge ist vermehrt, die Glyłosurie ist hochgradig, die Adrenalin dosis wird ohne jede Störung ertragen. The protocol given on p. 185 shows rather contradictory figures rê the amount of urine and sugar there.)

Lastly, a short account may be reported on the glycogen storage, mainly in rabbits, after splanchnicotomy and suprarenalectomy.

Double splanchnicotomy: A distinct decrease, such as by $40 \%$, was noted by Morita in rabbits 6-24 days after the operation, when the body weight recovered nearly completely. ${ }^{17}$ ) When a sufficient interval of time, such as a hundred days were allowed to elapse between the denervation and the glycogen assay, the liver and muscle glycogen of the operated rabbits were found only a little inferior to the normal values. ${ }^{18)} \mathrm{Nakatsuka}$ 's data ${ }^{197}$ are similar to $\mathrm{Mo-}$ rita, probably the rabbits were killed two weeks after the operation or later, as in Professor F ujii's laboratory, though actual data are not recorded there. The same question was attacked by Simizu on rabbits, ${ }^{20)}$ Best's histological method being relied on. 58 days were found as sufficient to see a complete recovery of glycogen storage in the liver. A statement that 30 days interval is sufficient to see a complete recovery is repeated in his conclusion too, but the data given in the text tell clearly its insufficiency. It is scarcely necessary to note what significance can be attached to such a histological examination for estimating the glycogen content.

$\mathrm{Sunaba} \mathrm{a}^{21)}$ estimated the glycogen content of liver in rabbits, 6 hours, 2 days, 5-7 days and two weeks after double splanchnicotomy; about twenty to thirty per cent reduction was noted there everywhere. Otherwise expressed, two weeks interval is not sufficient to see a complete recovery.

Double suprarenalectomy: There is no room to cite the results of the animals which did not survive long enongh double suprarenalectomy.

The liver glycogen content of a rabbit surviving the double suprarenalectomy over 8 months of $\mathrm{K}$ a h $\mathrm{n}$ and $\mathrm{Starkenste} \mathrm{in}^{16}$ (p. 189) was 6.1\%. The same figure was obtained by $S t e$ wart and $R \circ g$ of $f^{22}$ in a rabbit surviving the last decapsulation over one month. The Cleveland physiologists who carried out a great number of experiments of various kinds upon the rabbits indefinitely sur-

\footnotetext{
14) Viale, Kl. W., 1933, 12. year, 467.

15) Carraseo-Forminuera, Ann. de Physiol., 1933, 9, 905.

16) Kahn and Starkerstei n, Pflüger's Arch., 1911, 139, 185 ff.

17) M orita, Tohoku J. of Exp. Med., 1921, 2, 423 \& 436.

18) Mikami, Jap. J. Med. Sci., Pharm., 1926, 1, 125-129.

19) Nakatsuka, Mitt. med. Akad. Kioto, 1932, 6, 1427.

20) Simiz u, Kyoto Igaku Zassi, 1936, 33, 169.

21) Sunaba, Mitt. med. Akad. Kioto, 1936, 16, 1027.

22) Stewart and Rogoff, Am. J. of Physiol., 1918, 46, 90.
} 
viving the suprarenalectomy, estimated usually the glycogen storage after ending the experiment and found no noticeable variations there from the aninals without removing the glands. They are wholly correct in emphasizing the indispensability of estimating the glycogen content fordenying the hyperglycaemic ability of an agent or manipulation under question.

The glycogen storage of 4 rats surviving the double suprarenalectomy 13$2 \pm$ days, was found approximately the same as that in normal rats. It was only in trace in a rat, which was losing weight and killed 11 days after the operation. (The data rê the glycogen storage in the cats, deprived of one suprarenal gland and the nerves of the other, are identical with the rabbits, doubly suprarenaleetomized. ${ }^{22)}$ The same conclusion was reached by subseqnent workers in cats. The latter excised the suprarenal medulla of one gland besides the splanchnicotomy on that side and removal of the fellow gland. ${ }^{25}$ )

Catan, Houssay and Mazzoce ${ }^{24)}$ measured a rather greater amount of the liver glycogen in two rabbits killed 89 and 35 days, after the double suprarenalectomy $2.14 \%$ against $1.40 \%$ of the normal being the figures. The liver glyeogen was measured as $1.2750 ;$ in 21 rabbits, $7-28$ days after the double suprarenalectomy, against $1.519 \%$ of the controls.

$\mathrm{Kis} \mathrm{ch}^{(0)}$ noted parenthetically a rich storage of the liver glycogen in a rabbit surviving double suprarenalectomy for some months.

Working on rats, Shioz a w ${ }^{11)}$ estimated non-alteration of the liver glycogen storage by double suprarenalectomy. The absolute amount of glycogen of Shioz a wa was far smaller than that of Ste wart and Rog off.

Artund $0^{25}$ noted a diminution of liver glycogen in rats 3 and 8 days after the double decapsulation, and a considerably large amount (3.68\%) in 14 days after the decapsulation, and the normal value 32 days after it $(1.66 \%)$.

It may be noted further that there are papers reporting of non-influence of starration extending for a week upon the magnitude of adrenaline hyperglycaemia, otherwise expressed, no direct relation between the latter and the glycogen storage of animals. ${ }^{26}$ Whether such a view can be taken as holding true is still questionable, inasmuch as we have, for instance, another recent paper ${ }^{109}$ telling of a diminishing of the maximum increase of the blood sugar due to adrenaline in the rabbits starving for 6 days, or even for 2 days: this paper was probably overlooked by the latter investigator. ${ }^{26)}$

\section{METHODS.}

Rabbits of good nutrition, male or non-pregnant female, were experimented on. They were fed on tofukara, dry straw and carrot of 30-40 grms. per diem. Some few days prior to the adrenaline experi-

23) Britton, Geiling and Calvey, Ibid, 1928, 84, 154.

24) Catan, Houssay and Mazzoceo, C. r. Soc. Biol., 1921, 84, 164.

25) Artund o, C. r. Soc. Biol., 1927, 97, 411 .

26) Yoshio, J. of Biochem., 1937, 26, 49 (Some previous references there). 
ment, the ears were denervated for taking blood samples without pain and with ease. On the day before the adrenaline administration, the rabbit was brought into my laboratory room at just 2 o'clock in the afternoon, and thereafter no food was given.

The splanchnic nerves were bilaterally cut out about $7 \mathrm{cms}$. long per laparotomiam. Demedullation of the suprarenal glands was done through the lumbar route, as usual in this Laboratory. The suprarenal glands were excised through the lumbar way, about three weeks being allowed to elapse from removal of the right side to that of the left. No narcosis was resorted to at any operation.

The adrenaline administration was done while the animals looked wholly healthy, judging from their body weight, appetite and behaviour.

Blood samples were taken from the denervated ear vein, and estimated for sugar by the micro-method of Fujita and Iw atake, ${ }^{27)}$ which has some invaluable merits not to be found in that of $\mathrm{Hag} \mathrm{e}$ dorn and $\mathrm{Jensen}$, in that cadmium is used for preparing proteinfree blood filtrate instead of zinc, whereby glutathione, ergothioneine, and uric acid are completely removed off, etc.

The rate of heart beat and respiration, the rectal and room temperature were noted from time to time. At the adrenaline experiment the animal was not fastened, and no narcosis was used. Adrenaline chlorid (1:1000) of Sankyo Co. was subcutaneously injected in a few seconds in a uniform dosis of $0.2 \mathrm{mgrm}$. per kilo. On this dose usually some symptoms became manifest: slight dyspnoea, mydriasis, widening of the palpebral fissurae, bradycardia, then tachycardia, etc.

\section{DAtA.}

\section{Normal rabbits.}

As the control, 6 normal rabbits, 3 male and 3 female, were injected with adrenaline, in subcutaneous dose of $0.2 \mathrm{mgrm}$. per kilo, as above mentioned. The data are given in Table $\mathbf{I}$.

On adrenaline the blood sugar concentration increased from 0.097 grm. \% (0.086-0.103) to 0.269 grm. \% (0.235-0.300), which was measured 1-2 hours after the injection, so about $180 \%$ increase was thus established.

27) Fujita and I watake, Biochem, Ztschr., 1931, 242, 43; also in Fu jit a, Manometric methods and their application (Jap.), 1932 Iwanami, Tokyo, $95 \mathrm{ff}$. 


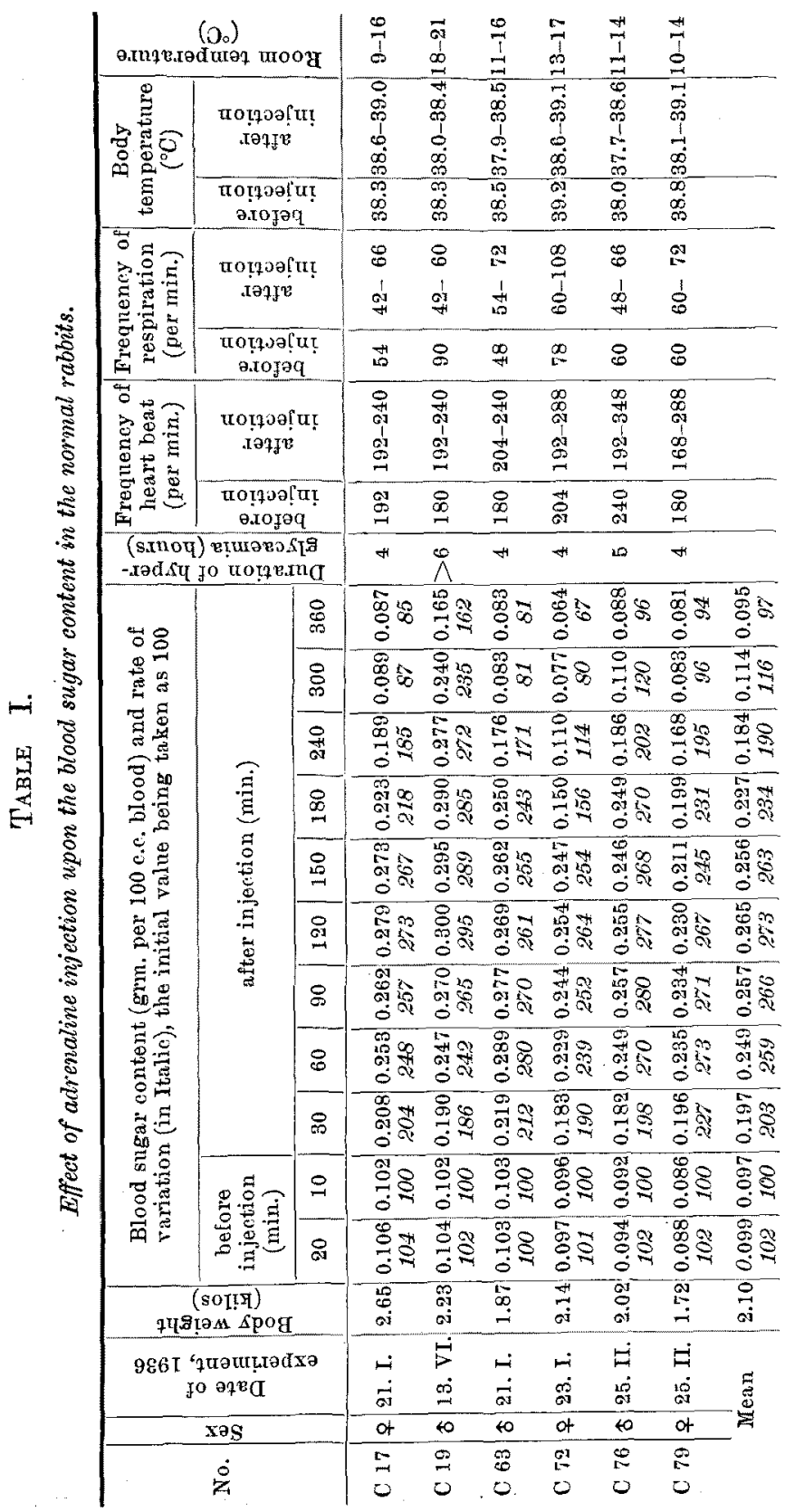


TABLE

Effect of alrenaline injection upon the blood sugar

\begin{tabular}{|c|c|c|c|c|c|c|c|c|c|c|c|c|c|}
\hline \multirow{4}{*}{ No. } & \multirow{4}{*}{$\operatorname{Sex}$} & \multicolumn{4}{|c|}{ Suprarenalectomy } & \multirow{4}{*}{ 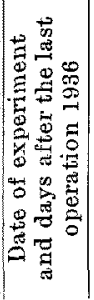 } & \multirow{4}{*}{ 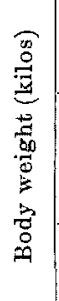 } & \multirow{2}{*}{\multicolumn{6}{|c|}{$\begin{array}{r}\text { Blood sugar content (grm. per } \\
\text { variation (in Italic) }\end{array}$}} \\
\hline & & \multicolumn{2}{|c|}{$\mathrm{R}$} & \multicolumn{2}{|c|}{$\mathrm{L}$} & & & & & & & & \\
\hline & & \multirow{2}{*}{ Date } & \multirow{2}{*}{ 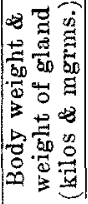 } & \multirow{2}{*}{ Date } & \multirow{2}{*}{ 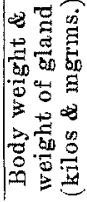 } & & & \multicolumn{2}{|c|}{$\begin{array}{c}\text { before } \\
\text { injection } \\
\text { (min.) }\end{array}$} & \multicolumn{4}{|r|}{ after } \\
\hline & & & & & & & & 20 & 10 & 30 & 60 & 90 & 120 \\
\hline $\mathrm{C} 3$ & $\delta$ & $\begin{array}{l}29 . \mathrm{Xr} \\
1934\end{array}$ & $\begin{array}{r}1.45 \\
113\end{array}$ & $\begin{array}{c}15 . \mathrm{TV} . \\
1935\end{array}$ & $\begin{array}{l}1.87 \\
247\end{array}$ & $\mid \begin{array}{c}200 . \\
285\end{array}$ & 1.89 & $\begin{array}{c}0.100 \\
98\end{array}$ & $\begin{array}{c}0.102 \\
100\end{array} \mid$ & $\begin{array}{l}0.207 \\
203\end{array}$ & $\begin{array}{c}0.254 \\
251\end{array}$ & $\begin{array}{c}0.258 \\
253\end{array} \mid$ & $\begin{array}{l}0.278 \\
272\end{array}$ \\
\hline C 5 & 우 & 3. $\mathrm{x}$. & 1.80 & 15. XI. & 1.90 & 25. $\quad \mathrm{I}$ & 2.53 & 0.086 & 0.090 & 0.142 & 0.188 & 0.259 & 0.241 \\
\hline & & 1934 & 120 & 1984 & 160 & 436 & & $9 \tilde{5}$ & 100 & 158 & 209 & 287 & $26 \%$ \\
\hline C 12 & $\delta$ & $\begin{array}{l}\text { 3. X. } \\
1934\end{array}$ & $\begin{array}{r}1.75 \\
132\end{array}$ & $\begin{array}{c}\text { 15. IV. } \\
1935\end{array}$ & $\begin{array}{r}1.90 \\
950\end{array}$ & $\begin{array}{l}\text { 5. III } \\
325\end{array}$ & 1.92 & $\begin{array}{c}0.100 \\
93\end{array}$ & $\begin{array}{c}0.107 \\
100\end{array}$ & $\begin{array}{l}0.230 \\
215\end{array}$ & $\begin{array}{l}0.855 \\
238\end{array}$ & $\begin{array}{c}0.257 \\
240\end{array}$ & $\begin{array}{c}0.283 \\
266\end{array}$ \\
\hline C 15 & $\delta$ & $\begin{array}{l}\text { 21. V. } \\
1935\end{array}$ & $\begin{array}{r}1.77 \\
128\end{array}$ & $\begin{array}{c}\text { 18. VI. } \\
1935\end{array}$ & $\begin{array}{r}1.75 \\
155\end{array}$ & $\begin{array}{c}\text { 5. III. } \\
261\end{array}$ & 2.25 & $\begin{array}{c}0.113 \\
104\end{array}$ & $\begin{array}{c}0.109 \\
100\end{array}$ & $\begin{array}{c}0.239 \\
219\end{array}$ & $\begin{array}{l}0.301 \\
276\end{array}$ & $\begin{array}{l}0.317 \\
291\end{array}$ & $\begin{array}{l}0.293 \\
268\end{array}$ \\
\hline H 6 & 우 & $\begin{array}{l}\text { 6. VI. } \\
1935\end{array}$ & $\begin{array}{r}1.80 \\
107\end{array}$ & $\begin{array}{c}29 . \mathrm{VI} . \\
1935\end{array}$ & $\begin{array}{r}1.59 \\
180\end{array}$ & $\mid \begin{array}{c}10 . \text { II. } \\
255\end{array}$ & 1.93 & $\begin{array}{c}0.090 \\
95\end{array}$ & $\left(\begin{array}{c}0.094 \\
100\end{array} \mid\right.$ & $\begin{array}{c}0.197 \\
209\end{array} \mid$ & $\begin{array}{c}0.235 \\
253\end{array}$ & $\begin{array}{c}0.271 \\
287\end{array}$ & $\begin{array}{l}0.252 \\
207\end{array}$ \\
\hline$H \quad 9$ & 古 & $\begin{array}{c}\text { 27. VI. } \\
1935\end{array}$ & $\begin{array}{r}1.80 \\
107\end{array}$ & $\begin{array}{c}16 . \text { VII. } \\
1935\end{array}$ & $\begin{array}{r}1.65 \\
132\end{array}$ & $\begin{array}{c}12 . V . \\
306\end{array}$ & 2.26 & $\begin{array}{c}0.108 \\
98\end{array}$ & $\begin{array}{c}0.110 \\
100\end{array}$ & $\begin{array}{c}0.182 \\
166\end{array}$ & $\begin{array}{l}0.245 \\
223\end{array}$ & $\left|\begin{array}{c}0.260 \\
237\end{array}\right|$ & $\begin{array}{l}0.290 \\
264\end{array}$ \\
\hline H 16 & 古 & $\begin{array}{l}28 . I X . \\
1935\end{array}$ & $\begin{array}{r}1.70 \\
80\end{array}$ & $\begin{array}{c}17 . \mathrm{X} \\
1935\end{array}$ & $\begin{array}{r}1.60 \\
130\end{array}$ & $\begin{array}{c}12 . \mathrm{V} . \\
208\end{array}$ & 2.4 .4 & $\begin{array}{c}0.096 \\
107\end{array}$ & $\begin{array}{c}0.090 \\
100\end{array}$ & $\begin{array}{c}0.171 \\
190\end{array}$ & $\begin{array}{l}0.227 \\
252\end{array}$ & $\left(\begin{array}{c}0.235 \\
260\end{array}\right.$ & $\begin{array}{l}0.254 \\
282\end{array}$ \\
\hline & & Iean & 1.72 & & 1.75 & & 2.17 & $\begin{array}{c}0.099 \\
99\end{array}$ & $\begin{array}{c}0.100 \\
100\end{array}$ & $\begin{array}{c}0.194 \\
194\end{array}$ & $\left|\begin{array}{c}0.244 \\
244\end{array}\right|$ & $\left|\begin{array}{c}0.265 \\
265\end{array}\right|$ & $\begin{array}{l}0.270 \\
269\end{array}$ \\
\hline
\end{tabular}

The hyperglycaemic period covered at least 4 hours, seldom over 6 hours (No. C 19).

After elapsing of the hyperglycaemic phase, the blood sugar concentration had a tendency to diminish under the initial value; it was remarkable in No. C 72.

If the average figure be composed, the adrenaline hyperglycaemia reaches its maximum, $0.265 \mathrm{grm}$. \% or an increase by $270 \%, 2$ hours after the injection, and the hyperglycaemic period extends for 5 hours. And the great hyperglycaemia period over $0.25 \mathrm{grm} . \%$ makes appearance one hour after the injection and lasts for 1.5 hours.

\section{Doubly suprarenalectomized rabbits.}

7 rabbits, 5 male and 2 female, were doubly suprarenalectomized, and 208-436 days later adrenaline injection was tried (Table II).

The initial blood sugar concentration was as a matter of course wholly normal (0.100 grm. \%-from $0.09 \mathrm{grm}$. \% to $0.11 \mathrm{grm}$. \%). 
II.

content in the doubly suprarenalectomized rabbits.

\begin{tabular}{l}
$\begin{array}{l}\text { 100 c.c. blood) and rate of } \\
\text { the initial as } 100\end{array}$ \\
\hline \\
injection (min.)
\end{tabular}

$0.2 \mathrm{mgrm}$. per kilo adrenaline hydrochloride, subeutaneously applied, occasioned a hyperglycaemia, the highest of which was 0.280 grm. $\%(0.254 \mathrm{grm} . \%-0.319 \mathrm{grm} . \%)$ and the duration of which was 5 hours (4-6 hours). The hyperglycaemic phase was followed by development of hypoglycaemia of small degree.

The average figures are quite identical with those in normal rabbits. The maximum was $0.270 \mathrm{grm} . \%$, the hyperglycaemic period lasted for 5 hours, the great hyperglycaemia period became manifest from 1 hour after the injection to 3 hours after it. Rather longer than in normal rabbits. The body weight of both series of experiments was almost the same.

\section{Doubly splanchnicotomized rabbits.}

7 rabbits, 3 male and 4 female, were excised of the splanchnic nerves in 7-10 cms. 70-320 days afterwards adrenaline hydrochloride was hypodermically given in the dose above stated (Table III). 
Table

Effect of adrenaline injection upon the blood sugar

\begin{tabular}{|c|c|c|c|c|c|c|c|c|c|c|c|}
\hline \multirow{3}{*}{ No. } & \multirow{3}{*}{$\operatorname{Sex}$} & \multicolumn{2}{|c|}{ Splanchnicotomy } & \multirow{3}{*}{$\begin{array}{c}\text { Date of } \\
\text { experi- } \\
\text { ment \& } \\
\text { days after } \\
\text { operation } \\
1936\end{array}$} & \multirow{3}{*}{ 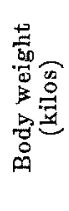 } & \multicolumn{6}{|c|}{$\begin{array}{l}\text { Blood sugar content (grm, per } \\
\text { variations (in Italic), the }\end{array}$} \\
\hline & & \multirow[t]{2}{*}{ Date } & \multirow{2}{*}{$\begin{array}{l}\text { Body } \\
\text { weight } \\
\text { (kilos) }\end{array}$} & & & \multicolumn{2}{|c|}{$\begin{array}{c}\text { before } \\
\text { injection }\end{array}$} & \multicolumn{4}{|r|}{ after } \\
\hline & & & & & & 20 & 10 & 30 & 60 & 90 & 120 \\
\hline C 26 & 우 & 30. VII. 1935 & 1.58 & $\begin{array}{l}\text { 6. VI. } \\
320\end{array}$ & 2.41 & $\begin{array}{c}0.107 \\
102\end{array}$ & $\begin{array}{c}0.105 \\
100\end{array}$ & $\begin{array}{c}0.212 \\
202\end{array}$ & $\begin{array}{c}0.242 \\
231\end{array}$ & $\begin{array}{l}0.260 \\
248\end{array}$ & $\begin{array}{l}0.262 \\
250\end{array}$ \\
\hline C 60 & $\$$ & 6. XII. 1935 & 1.68 & $\begin{array}{c}\text { 6. VI. } \\
183\end{array}$ & 1.87 & $\begin{array}{c}0.108 \\
104\end{array}$ & $\begin{array}{c}0.104 \\
100\end{array}$ & $\begin{array}{c}0.160 \\
154\end{array}$ & $\begin{array}{l}0.220 \\
211\end{array}$ & $\begin{array}{l}0.226 \\
217\end{array}$ & $\begin{array}{l}0.233 \\
223\end{array}$ \\
\hline C 67 & ๙ & 18. XII. 1935 & 1.72 & 26. $\underset{70}{\text { II. }}$ & 1.95 & $\begin{array}{c}0.096 \\
102\end{array}$ & $\begin{array}{c}0.094 \\
100\end{array}$ & $\begin{array}{c}0.196 \\
208\end{array}$ & $\begin{array}{c}0.249 \\
265\end{array}$ & $\begin{array}{c}0.254 \\
270\end{array}$ & $=\begin{array}{c}0.274 \\
291\end{array}$ \\
\hline C 80 & 우 & 18. XII. 1935 & 1.80 & 26. II. & 2.13 & $\begin{array}{c}0.094 \\
99\end{array}$ & $\begin{array}{c}0.095 \\
100\end{array}$ & $\begin{array}{c}0.175 \\
185\end{array}$ & $\begin{array}{c}0.222 \\
235\end{array}$ & $\begin{array}{l}0.242 \\
254\end{array}$ & $\begin{array}{l}0: 260 \\
274\end{array}$ \\
\hline C 88 & 우 & 23. I. 1936 & 1.92 & $\begin{array}{c}\text { 24. VI. } \\
184\end{array}$ & 2.25 & $\begin{array}{c}0.108 \\
100\end{array}$ & $\begin{array}{c}0.108 \\
100\end{array}$ & $\left|\begin{array}{c}0.193 \\
179\end{array}\right|$ & $\begin{array}{l}0.235 \\
218\end{array}$ & $\begin{array}{l}0.258 \\
240\end{array}$ & $\begin{array}{l}0.258 \\
240\end{array}$ \\
\hline C 89 & 우 & 23. I. 1936 & 1.70 & $\begin{array}{c}\text { 24. VI. } \\
184\end{array}$ & 2.01 & $\begin{array}{c}0.108 \\
97\end{array}$ & $\begin{array}{c}0.111 \\
100\end{array}$ & $\begin{array}{c}0.152 \\
137\end{array}$ & $\begin{array}{c}0.211 \\
190\end{array}$ & $\begin{array}{l}0.243 \\
219\end{array}$ & $\begin{array}{c}0.243 \\
219\end{array}$ \\
\hline C 94 & 定 & & 1.82 & $\begin{array}{c}\text { 13. VI. } \\
173\end{array}$ & 2.17 & $\begin{array}{c}0.095 \\
98\end{array}$ & $\begin{array}{c}0.097 \\
100\end{array}$ & $\begin{array}{c}0.190 \\
198\end{array}$ & $\begin{array}{c}0.243 \\
250\end{array}$ & $\begin{array}{l}0.282 \\
290\end{array}$ & $\begin{array}{l}0.305 \\
315\end{array}$ \\
\hline & & Mean & 1.74 & & 2.11 & $\left|\begin{array}{c}0.102 \\
100\end{array}\right|$ & $\begin{array}{c}0.102 \\
100\end{array}$ & $\left|\begin{array}{c}0.182 \\
180\end{array}\right|$ & $\begin{array}{c}0.231 \\
230\end{array}$ & $\begin{array}{c}0.252 \\
248\end{array}$ & $\begin{array}{l}0.262 \\
259\end{array}$ \\
\hline
\end{tabular}

The maximum sugar content of blood was then $0.280 \mathrm{grm} . \%$ $(0.258 \mathrm{grm} . \%$ to $0.305 \mathrm{grm} . \%)$ or it exceeded the initial by $180 \%$ $(140 \%-215 \%)$. The highest level appeare commonly 2 hours after the injection, and the hyperglycaemic spell continued for 5-6 hours or more; that is, the highest level was practically identical with the rabbits normal or doubly suprarenalectomized, but the hyperglycaemic phase lasted somewhat longer. The hyperglycaemia over $0.25 \mathrm{grm}$. $\%$ continued only for 1.5 hours.

If the experiments were extended longer, there would be perceived a development of hypoglycaemic period.

\section{Doubly medulli-suprarenalectomized rabbits.}

7 rabbits, 6 mole and 1 female, were removed of the suprarenal medulla, and 246 to 420 days later adrenaline was given in the above mentioned dose and manner (Table IV).

The initial blood sugar content was wholly the same as the normal rabbits. That bilateral interference of the splanchnic nerves, the suprarenal glands or the suprarenal medulla does not alter the blood sugar 
III.

content in the doubly splanchnicotomized rabbits.

\begin{tabular}{|c|c|c|c|c|c|c|c|c|c|c|c|c|}
\hline \multicolumn{5}{|c|}{$\begin{array}{l}100 \text { c.c. blood) and rate of } \\
\text { initial, as } 100\end{array}$} & \multirow{3}{*}{ 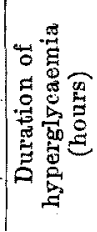 } & \multicolumn{2}{|c|}{$\begin{array}{c}\text { Frequency of } \\
\text { heart beat } \\
\text { (per min.) }\end{array}$} & \multicolumn{2}{|c|}{$\begin{array}{c}\text { Frequency of } \\
\text { respiration } \\
\text { (per min.) }\end{array}$} & \multicolumn{2}{|c|}{$\left[\begin{array}{c}\text { Body } \\
\text { temperature } \\
\left({ }^{\circ} \mathrm{C}\right)\end{array}\right.$} & \multirow{3}{*}{ 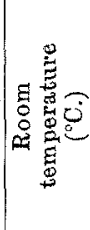 } \\
\hline & & & & & & \multirow{2}{*}{ 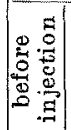 } & \multirow{2}{*}{ 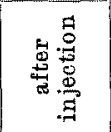 } & \multirow{2}{*}{ 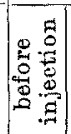 } & \multirow{2}{*}{ 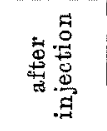 } & \multirow{2}{*}{ 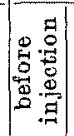 } & \multirow{2}{*}{ 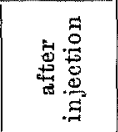 } & \\
\hline 150 & 180 & 240 & 300 & 360 & & & & & & & & \\
\hline $\begin{array}{c}0.275 \\
262\end{array}$ & $\begin{array}{c}0.282 \\
270\end{array}$ & $\begin{array}{c}0.232 \\
222\end{array}$ & $\mid \begin{array}{c}0.199 \\
189\end{array}$ & $\begin{array}{c}0,124 \\
118\end{array}$ & 6 & 168 & $90-216$ & 72 & $42-120$ & 38.0 & $37.8-38.6$ & $17-21$ \\
\hline $\begin{array}{c}0.237 \\
228\end{array}$ & $\begin{array}{l}0.255 \\
245\end{array}$ & $\begin{array}{l}0.247 \\
237\end{array}$ & $\begin{array}{c}0.233 \\
223\end{array}$ & $\mid \begin{array}{c}0.210 \\
202\end{array}$ & 6 & 216 & $240-319$ & 96 & $84-144$ & 38.0 & $37.1-38.1$ & $17-21$ \\
\hline $\begin{array}{c}0.252 \\
268\end{array}$ & $\begin{array}{c}0.212 \\
225\end{array}$ & $\begin{array}{c}0.176 \\
187\end{array}$ & $\begin{array}{c}0.112 \\
119\end{array}$ & $\begin{array}{c}0.092 \\
98\end{array}$ & 5 & 252 & $204-300$ & 72 & $48-108$ & $|38.5|$ & $38.5-38.9$ & $12-17$ \\
\hline $\begin{array}{l}0.230 \\
242\end{array}$ & $\begin{array}{l}0.203 \\
214\end{array}$ & $\begin{array}{c}0.124 \\
132\end{array}$ & $\begin{array}{c}0.103 \\
109\end{array}$ & $\mid \begin{array}{c}0.079 \\
83\end{array}$ & 5 & 300 & $240-300$ & 60 & $49-72$ & 38.4 & $38.6-38.9$ & $12-17$ \\
\hline $\begin{array}{l}0.242 \\
225\end{array}$ & $\begin{array}{c}0.238 \\
221\end{array}$ & $\begin{array}{c}0.155 \\
144\end{array}$ & $\begin{array}{c}0.115 \\
107\end{array}$ & $\begin{array}{c}0.106 \\
98\end{array}$ & 5 & 192 & $96-228$ & 84 & 54-.90 & 38.1 & $38.2-39.0$ & $20-93$ \\
\hline $\begin{array}{c}0.270 \\
243\end{array}$ & $\begin{array}{l}0.279 \\
245\end{array}$ & $\begin{array}{c}0.291 \\
262\end{array}$ & $\begin{array}{c}0.252 \\
227\end{array}$ & $\begin{array}{c}0.177 \\
159\end{array}$ & 6 & 216 & $120 \quad 228$ & 60 & $48-78$ & 38.2 & $37.7-38.5$ & $20-23$ \\
\hline $\begin{array}{c}0.280 \\
290\end{array}$ & $\begin{array}{c}0.270 \\
278\end{array}$ & $\begin{array}{l}0.235 \\
242\end{array}$ & $\begin{array}{c}0.168 \\
174\end{array}$ & $\begin{array}{c}0.109 \\
112\end{array}$ & 6 & 216 & $216-264$ & 120 & $84-156$ & 38.4 & $38.4-38.7$ & $18-21$ \\
\hline $\begin{array}{c}0.255 \\
251\end{array}$ & $\mid \begin{array}{c}0.247 \\
242\end{array}$ & $\begin{array}{c}0.208 \\
203\end{array}$ & $\left|\begin{array}{c}0.169 \\
164\end{array}\right|$ & $\mid \begin{array}{c}0.128 \\
124\end{array}$ & & & & & & & & \\
\hline
\end{tabular}

concentration in the quiet state of animals, without disturbed carbohydrate metabolism, is a well established fact. It is quite superfluous nowadays to repeat such a statement.

Adrenaline injection brought about in these medulli-suprarenalectomized rabbits a hyperglycaemia of quite the same magnitude and duration, $0.271 \mathrm{grm} . \%$ (0.233 grm. \%-0.294 grm. \%) or an increase of $173 \%(133 \%$ to $167 \%)$ and 5 hours (4-6 hours) being estimated. The hyperglycaemia above $0.25 \mathrm{grm} . \%$ lasted in the average one hour. Hypoglycaemic phase was detected in almost all cases.

We are thus qualified to conclude non-effectivenes of double splanchnicotomy, suprarenalectomy or medulli-suprarenalectomy upon the magnitude and the course of hyperglycaemia due to adrenaline; in the present instance, investigations were carried out a considerable length of time after the operation. And the present outcome coincides with the results of previous investigators who were carefully observant as to the nutritious state of the animals. If one carries out the experiment when animals cannot be considered normal, excepting the necessary results occasioned by loss of the splanchnic nerves, suprarenals or suprarenal medulla itself; one will see a small hyperglycaemia or 
TABLE

Effect of adrenaline injection upon the blood sugar

\begin{tabular}{|c|c|c|c|c|c|c|c|c|c|c|c|c|c|}
\hline \multirow{4}{*}{ No. } & \multirow{4}{*}{ Sex } & \multicolumn{4}{|c|}{ Demedullation } & \multirow{4}{*}{ 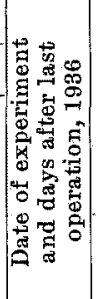 } & \multirow{4}{*}{ 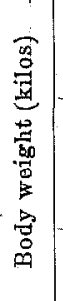 } & \multirow{2}{*}{\multicolumn{6}{|c|}{$\begin{array}{r}\text { Blood sugar content (grm. per } \\
\text { variations, the }\end{array}$}} \\
\hline & & \multicolumn{2}{|c|}{$\mathbf{R}$} & \multicolumn{2}{|c|}{$\mathrm{L}$} & & & & & & & & \\
\hline & & \multirow{2}{*}{ 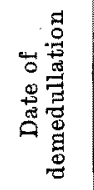 } & \multirow{2}{*}{ 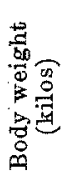 } & \multirow{2}{*}{ 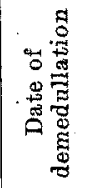 } & \multirow{2}{*}{ 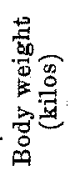 } & & & \multicolumn{2}{|c|}{$\begin{array}{l}\text { before } \\
\text { injection } \\
\text { (min.) }\end{array}$} & \multicolumn{4}{|r|}{ after } \\
\hline & & & & & & & & 20 & 10 & 30. & 60 & 90 & 120 \\
\hline C 28 & q & & 1.69 & $\begin{array}{c}\text { 15. III. } \\
1935\end{array}$ & 1.95 & & 2.18 & $\begin{array}{c}0.093 \\
102\end{array}$ & $\begin{array}{c}0.091 \\
100\end{array}$ & $\begin{array}{c}0.176 \\
194\end{array}$ & $\begin{array}{c}0.235 \\
258\end{array}$ & $\begin{array}{c}0.278 \\
305\end{array}$ & $\begin{array}{c}0.272 \\
300\end{array}$ \\
\hline C 29 & $\delta$ & $\begin{array}{l}6 . \quad \mathrm{V} . \\
1935\end{array}$ & 1.58 & $\begin{array}{l}\text { 8. VII. } \\
1935\end{array}$ & 1.65 & 12. III. & 2.07 & $\begin{array}{l}0.113 \\
103\end{array}$ & $\begin{array}{c}0.110 \\
100\end{array}$ & $\begin{array}{c}0.209 \\
190\end{array}$ & $\begin{array}{c}0.264 \\
240\end{array}$ & $\begin{array}{l}0.285 \\
259\end{array}$ & $\begin{array}{l}0.294 \\
267\end{array}$ \\
\hline C 32 & & $\begin{array}{c}13 . \mathrm{V} . \\
1935\end{array}$ & 1.55 & $\begin{array}{l}\text { 8. VII. } \\
1935\end{array}$ & 1.57 & $\begin{array}{c}\text { 12. III. } \\
249\end{array}$ & 1.90 & $\begin{array}{c}0.096 \\
102\end{array}$ & $\begin{array}{c}0.094 \\
100\end{array}$ & $\begin{array}{c}0.186 \\
197\end{array}$ & $\begin{array}{l}0.230 \\
244\end{array}$ & $\begin{array}{c}0.254 \\
269\end{array}$ & $\begin{array}{l}0.261 \\
277\end{array}$ \\
\hline H 3 & $\widehat{\delta}$ & $\begin{array}{c}14 . \mathrm{VI} \\
1935\end{array}$ & 1.75 & $\begin{array}{l}\text { 9. VII. } \\
1935\end{array}$ & 1.65 & $\mid \begin{array}{c}11 . \text { III } \\
246\end{array}$ & 2.20 & $\begin{array}{c}0.118 \\
106\end{array}$ & $\begin{array}{c}0.111 \\
100\end{array}$ & $\begin{array}{c}0.214 \\
193\end{array}$ & $\begin{array}{c}0.225 \\
202\end{array}$ & $\begin{array}{l}0.288 \\
255\end{array}$ & $\begin{array}{l}0.287 \\
258\end{array}$ \\
\hline H 4 & $\delta$ & $\begin{array}{c}\text { 13. VI. } \\
1935\end{array}$ & 1.78 & $\begin{array}{l}\text { 2. VII. } \\
1935\end{array}$ & 1.74 & $\begin{array}{c}11 . \text { III } \\
253\end{array}$ & 2.05 & $\begin{array}{c}0.085 \\
102\end{array}$ & $\begin{array}{c}0.083 \\
100\end{array}$ & $\begin{array}{c}0.186 \\
224\end{array}$ & $\begin{array}{c}0.245 \\
295\end{array}$ & $\left|\begin{array}{c}0.267 \\
323\end{array}\right|$ & $\begin{array}{l}0.292 \\
352\end{array}$ \\
\hline H 5 & 今 & $\begin{array}{c}13 . \mathrm{VI} \\
1935\end{array}$ & 1.70 & $\begin{array}{l}\text { 2. VII. } \\
1935\end{array}$ & 1.75 & $\begin{array}{c}\text { 8. V. } \\
311\end{array}$ & 2.01 & $\begin{array}{c}0.119 \\
104\end{array}$ & $\begin{array}{c}0.114 \\
100\end{array}$ & $\begin{array}{c}0.207 \\
182\end{array}$ & $\begin{array}{c}0.252 \\
222\end{array}$ & $\left|\begin{array}{c}0.245 \\
215\end{array}\right|$ & $\begin{array}{l}0.236 \\
20 \%\end{array}$ \\
\hline H 18 & ڤ & $\begin{array}{c}21 . \mathrm{IX} . \\
1935\end{array}$ & 2.13 & $\underset{1935}{14 . \quad X}$ & 1.99 & $\begin{array}{c}\text { 17. VI. } \\
247\end{array}$ & 2.17 & $\begin{array}{c}0.109 \\
109\end{array}$ & $\begin{array}{c}0.100 \\
100\end{array}$ & $\begin{array}{c}0.180 \\
180\end{array}$ & $\begin{array}{c}0.201 \\
201\end{array}$ & $\begin{array}{c}0.233 \\
233\end{array}$ & $\begin{array}{l}0.204 \\
204\end{array}$ \\
\hline & & Iean & 1.73 & & 1.76 & & 2.08 & $\left|\begin{array}{c}0.105 \\
104\end{array}\right|$ & $\begin{array}{c}0.100 \\
100\end{array}$ & $\begin{array}{c}0.194 \\
194^{\circ}\end{array}$ & $\begin{array}{c}0.236 \\
237\end{array}$ & $\left|\begin{array}{c}0.263 \\
265\end{array}\right|$ & $\int \begin{array}{c}0.264 \\
266\end{array}$ \\
\hline
\end{tabular}

none, as given in the inductory. Some writers failed to draw a proper conclusion from their correct data.

The findings, that double splanchnictomy, suprarenalectomy and medulli-suprarenalectomy do. not act to alter the hyperglycaemic ability of adrenaline, while they intensify the hypoglycaemic action of insulin, ${ }^{28)}$ can be at least chiefly explainable by the facts that the former has no accelerating action upon the epinephrine output rate, ${ }^{29}$ contrary to the latter. ${ }^{30)}$

\section{SuMmary.}

Adrenaline hydrochloride was given in the dose of $0.2 \mathrm{mgrm}$. per kilo of body weight into rabbits, long surviving bilaterally swprarenalectomized, medulli-suprarenalectomized or splanchnictomized and

28) Ohmi, Tohoku J. of Exp. Med., 1933, 21, 211.

99) Sugawara, Saito and Nem oto, Ibid., 1927, 9, 149.

30) Yen, A om ura and Inaba, Ibid., 1933, 21, 542. 
IV.

content in the medulli-suprarenalectomized rabbits.

\begin{tabular}{|c|c|c|c|c|c|c|c|c|c|c|c|c|}
\hline \multicolumn{5}{|c|}{$\begin{array}{l}100 \text { c.c. blood) and rate of } \\
\text { initial as } 100\end{array}$} & \multirow{3}{*}{ 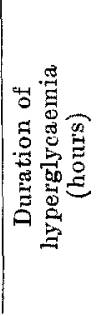 } & \multicolumn{2}{|c|}{$\begin{array}{c}\text { Frequeney of } \\
\text { heart beat } \\
\text { (per min.) }\end{array}$} & \multicolumn{2}{|c|}{$\begin{array}{c}\text { Frequency of } \\
\text { respiration } \\
\text { (per min.) }\end{array}$} & \multicolumn{2}{|c|}{$\begin{array}{c}\text { Body } \\
\text { temperature } \\
\left({ }^{\circ} \mathrm{C} .\right)\end{array}$} & \multirow{3}{*}{ 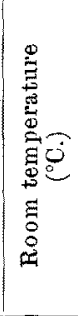 } \\
\hline \multicolumn{5}{|c|}{ injection (min.) } & & $\circ 0$ & & 05 & & & है & \\
\hline 150 & 180 & 240 & 300 & 360 & & & $=$ & $\approx$ & & & & \\
\hline $\begin{array}{c}0.223 \\
240\end{array}$ & $\begin{array}{c}0.170 \\
187\end{array}$ & $\begin{array}{c}0.114 \\
125\end{array}$ & $\begin{array}{c}0.078 \\
86\end{array}$ & $\begin{array}{c}0.078 \\
86\end{array}$ & 4 & 192 & $96-240$ & 102 & $60-114$ & 38.5 & $38.6-39.2$ & $14-18$ \\
\hline 0.285 & 0.254 & 0.174 & 0.108 & 0.087 & 4 & 240 & $216-300$ & 54 & $36-72$ & 38.1 & $37.5-38.2$ & $13-20$ \\
\hline 259 & 231 & 158 & 98 & 79 & & & & & & & & \\
\hline $\begin{array}{c}0.244 \\
259\end{array}$ & $\mid \begin{array}{c}0.223 \\
236\end{array}$ & $\left|\begin{array}{c}0.113 \\
120\end{array}\right|$ & $\begin{array}{c}0.106 \\
112\end{array}$ & $\begin{array}{c}0.073 \\
77\end{array}$ & 5 & 840 & $180-300$ & 72 & $78-120$ & 38.2 & $38.2-38.7$ & $14-20$ \\
\hline $\begin{array}{c}0.288 \\
250\end{array}$ & {$\left[\begin{array}{c}0.287 \\
258\end{array}\right.$} & $\left|\begin{array}{c}0.255 \\
229\end{array}\right|$ & $\begin{array}{c}0.188 \\
169\end{array}$ & $\begin{array}{c}0.126 \\
113\end{array}$ & 6 & 264 & $240-312$ & 72 & $60-120$ & 38.5 & $38.4-38.6$ & $11-18$ \\
\hline $\begin{array}{c}0.281 \\
340\end{array}$ & $\mid \begin{array}{c}0.260 \\
314\end{array}$ & $\begin{array}{c}0.183 \\
220\end{array}$ & $\begin{array}{c}0.071 \\
85\end{array}$ & $\begin{array}{c}0.068 \\
82\end{array}$ & 4 & 204 & $240-324$ & 60 & $54-78$ & 38.3 & $38.7-39.0$ & $12-18$ \\
\hline 0.229 & 0.188 & 0.158 & 0.106 & 0.093 & 4 & 216 & $216-300$ & 78 & $60-90$ & 38.8 & $38.3-38.8$ & $14-18$ \\
\hline 200 & 165 & 139 & 93 & 82 & & & & & & & & \\
\hline 0.189 & 0.173 & 0.114 & 0.090 & 0.082 & 4 & 216 & $180-240$ & 72 & $48-108$ & 38.6 & $37.7-38.6$ & $21-25$ \\
\hline 189 & 173 & 114 & 90 & 82 & & & & & & & & \\
\hline $\begin{array}{c}0.248 \\
249\end{array}$ & $\begin{array}{l}0.222 \\
.223\end{array}$ & $\begin{array}{c}0.159 \\
158\end{array}$ & $\begin{array}{c}0.107 \\
105\end{array}$ & $\left|\begin{array}{c}0.087 \\
86\end{array}\right|$ & & & & & & & & \\
\hline
\end{tabular}

living in good nutritive conditions.

In respect to the magnitude and comse of hyperglycaemia, these animals did not differ at all from the normal control animals.

On thoroughly reviewing the previous reports, the present writer can point out why some of them arrived at a different conclusion. Some of the latter injected adrenaline when the animals were suffering from the operation itself, not from the loss of the nerves or glands, or when the animals were already moribund, and another made an erronous conclusion in spite of correct data obtained. 